\title{
Politik dan Ekonomi di Dua Kota: Baubau dan Kendari pada tahun 1950-an-1960-an
}

\section{(The Politics and Economy in Two Towns: Baubau and Kendari in 1950s-1960s)}

\author{
La Ode Rabani* \\ Bambang Purwanto** \\ Sri Margana** \\ ${ }^{*}$ Departemen Sejarah - Universitas Airlangga, ${ }^{* *}$ Departemen Sejarah - Universitas Gadjah Mada. \\ Jalan Dharmawangsa Dalam, Surabaya \\ Tel.: +62 (31) 5035676 \\ Surel: laode-rabani@fib.unair.ac.id
}

Diterima: 21 Oktober 2019 Direvisi: 15 Juli $2020 \quad$ Disetujui: 25 Juli 2020

\begin{abstract}
Abstrak
Artikel ini menjelaskan implikasi kekacauan politik-ekonomi pada perkembangan dua kota, yakni Baubau dan Kendari tahun 1950-an sampai 1960-an. Periode 1950an bagi Indonesia pada umumnya dan Sulawesi Tenggara pada khususnya secara politik dan ekonomi tidak stabil. Hal itu terjadi karena negara masih dalam taraf mencari keseimbangan dan konsolidasi politik dan ekonomi yang belum mencapai titik kesimbangan. Akibatnya, kekacauan politik terjadi di daerah-daerah tertentu karena perbedaan pandangan, termasuk di Sulawesi Selatan dan Sulawesi Tenggara. Salah satu gangguan politik yang berpengaruh pada perkembangan kota adalah pemberontakan DI/TII yang terjadi pada tahun 1950-an. Salah satu dampak dari kekacauan politik di dua kota, Buton dan Kendari, adalah mengalirnya penduduk pedesaan ke perkotaan. Operasi militer untuk menghilangkan gangguan keamanan di Kota Baubau dan Kendari mendukung peningkatan infrastruktur untuk akses ke kota, dan memperluas morfologis kota. Penulis memeriksa, membaca, dan memeriksa dokumen dan arsip secara cermat di Sulawesi Selatan dan Sulawesi Tenggara. Fakta di arsip menunjukkan bahwa guncangan politik dan ekonomi memiliki efek yang baik pada satu hal dan tidak baik pada hal lain. Peristiwa kekacauan politik di Sulawesi Tenggara memberikan pelajaran dan pengetahuan penting tentang sisi lain dari kekacauan politik dan ekonomi.
\end{abstract}

Kata kunci: Baubau dan Kendari, kekacauan politik dan ekonomi, perkembangan kota

\begin{abstract}
This study aims to reveal the implications of political-economic shock on the development of two towns; Baubau and Kendari in the 1950s to 1960s. Indonesia in the 1950s general and especially Southeast Sulawesi were politically and economically unstable. This situation happened because the country is still on the stage of finding a balance and political and economic consolidation has not reached the point of equilibrium. As a result, political shock occurred in certain areas due to differences in views, including in South Sulawesi and Southeast Sulawesi. One of the political disturbances that influenced the development of the towns was the DI/TII rebellion in the 1950s. One of the effects of political turmoil in two cities, Buton and Kendari, is the flow of rural populations into towns. Military operations to eliminate security disturbances in the towns of Baubau
\end{abstract}


and Kendari support the improvement of infrastructure for access to the town and expand morphology of towns. The author examines, reads, and examines documents archives carefully in South and Southeast Sulawesi. The facts in the archives show that political and economic shocks have a good effect on one thing and not good on another side. The events of political turmoil in Southeast Sulawesi provide important lessons and knowledge about the other side of political and economic shocks.

Keywords: politic and economy shock, trends of town, Baubau and Kendari towns

\section{PENDAHULUAN}

Secara geografis, Kota Baubau dan Kendari berlokasi di pulau yang berbeda. Kendari berada satu daratan dengan Pulau Sulawesi, yakni di tanjung tenggara, sedangkan Buton adalah pulau tersendiri dan terpisah dari daratan tanjung tenggara Pulau Sulawesi. Kota Baubau berlokasi di sisi darat Teluk Baubau, dan kota Kendari berada di sisi darat Teluk Kendari. Lokasi kedua kota berada dalam lalu lintas dan jaringan perdagangan internasional yang terhubung dengan pusat produksi rempahrempah di Kepulauan Maluku dan pusat perkapalan dan pengangkutan di Makassar, Surabaya, dan Singapore. Konektivitas perdagangan dengan Singapore dimainkan oleh para pedagang Bugis untuk melakukan perdagangan hasil laut seperti lola, teripang, dan mutiara (Sutherland 2004; Knaap dan Sutherland 2004; Findlay dan O’Rourke 2001).

Sejarah Indonesia tahun 1950-an didominasi oleh sejarah politik. Hal itu tidak lepas dari suasana pemikiran dan situasi Indonesia saat itu. Krisis politik yang dialami bangsa Indonesia sejak era kolonial, masa penjajahan Jepang, dan pasca-Indonesia merdeka. Depresi ekonomi yang terjadi hingga mencapai inflasi naik 650 persen tidak lepas dari situasi politik yang "gaduh." Suasana revolusi mempertahankan kemerdekaan (1945-1949), pemberontakan di daerah, dan kabinet yang tidak mapan telah membuka celah kekacauan dan mewariskan situasi politik yang tidak stabil.

Kondisi yang sama juga terjadi pada level lokal. Di Sulawesi, suasana politik sangat hangat yang ditandai dengan kekacauan politik menjelang pemilu 1955 dan juga lahirnya gerakan DI/TII yang awalnya berpusat di Makassar. Akan tetapi, gerakan itu meluas di hampir seluruh Sulawesi (Harvey 1987a), termasuk ke Buton dan Kendari. Tulisan ini menjelaskan dampak gerakan kekacauan politik pada dua kota, yakni Baubau dan Kendari. Bagaimana politik memengaruhi perkembangan kota dan mengapa kekacauan politik di Sulawesi Tenggara berkontribusi pada perkembangan dua kota pelabuhan, Baubau dan Kendari? Dari penelusuran penulis, kaitan antara kekacauan politik dan perkembangan kota jarang mengisi ruang ilmu pengetahuan Indonesia, khususnya sejarah.

Oleh karena itu, tulisan ini hadir untuk menambah perspektif baru bahwa kekacauan politik ternyata membawa konsekuensi yang tidak pernah diperkirakan sebelumnya, khususnya pada era di mana akses informasi dan infrastruktur masih terbatas. Aspek sumber daya (ekonomi) menjadi pembenar atas tindakan menuntut otonomi daerah bagi perjuangan pembentukan Provinsi Sulawesi Timur pada tahun 1950-an-1960-an (Rabani 2005a). Beberapa karya yang terkait dengan dua kota yang diteliti antara lain berasal dari Duke (1997a) dengan judul "Pembentukan Propinsi Sulawesi Tenggara 1950-1978: Studi Konflik dan Integrasi." Studi Said D. berbasis pada dokumen resmi sehingga dapat disebut sebagai sejarah formal. Proses dan tuntutan elite lokal untuk pembentukan Provinsi Sulawesi Timur diulas dengan baik. Tulisan Said D. menjelaskan proses pembentukan Sulawesi Tenggara dari sisi politik, di mana akar pembentukan Sulawesi Tenggara berasal dari tuntutan pembentukan Propinsi Sulawesi Timur melalui keputusan Kementerian Dalam Negeri dan Otonomi Daerah pada tahun 1964. 
Karya yang terkait dengan artikel ini di antaranya adalah Rabani (2005b); Syahadat, Arifin, dan Susilo (2016); Rabani (2016), Melamba, Salahuddin, dan Janu (2011). Hubungan ekonomi dan politik telah ditulis oleh I Gde Parimarta dan Edward Poelinggomang (Poelinggomang 2004; Parimartha 2002). Karya-karya itu tidak menghubungkan kekacauan politik dan ekonomi yang memengaruhi perkembangan kota. Karya-karya itu juga berbeda dari sisi sudut pandangnya dan data-data yang digunakan. Rabani (2005b), misalnya, tidak menghadirkan pengetahuan tentang kaitan antara aspek kekacauan politik yang mendukung perkembangan kota, demikian juga Melamba, Salahuddin, dan Janu (2011). Sementara itu, Syahadat, Arifin, dan Susilo lebih melihat peranan kolonial dalam pembentukan struktur lanskap Kota Baubau. Karya itu memberi latar historis pada tulisan ini, sejauh mana struktur kota dipengaruhi oleh intervensi kolonial. Karya Rabani (2016) sudah menghadirkan aspek kekacauan sosial yang memengaruhi perkembangan Kota Kendari. Jadi, dari sudut pandang itu, artikel ini berbeda dengan karya sebelumnya di mana tulisan ini menggunakan dua perspektif, yakni politik dan ekonomi memengaruhi perkembangan dua kota pelabuhan, Baubau dan Kendari, periode 1950-an-1960-an.

\section{METODE}

Untuk menemukan dan mencapai tujuan dari suatu penelitian, metode menjadi syarat wajib. Metode dibutuhkan untuk efektivitas aksesibilitas, khususnya pada aspek menemukan sumber, menganalisis data, menemukan fakta, dan menyusun explanasi peristiwa sejarah yang ditulis. Adapun metode yang digunakan pada penelitian ini adalah metode sejarah. Dengan metode sejarah, tujuan penelitian yang ditetapkan sejak awal, yakni menganalisis dampak kekacauan politik di tingkat lokal pada perkembangan kota, khususnya pada sisi demografi, infrastruktur, dan perluasan morfologis kota. Langkah-langkah penelitian mengacu pada metode sejarah yang ditulis oleh Kuntowijoyo. Pada tahap awal, peneliti sejarah harus mentukan topik, selanjutnya melakukan pencarian sumber, menyeleksi, melakukan kritik sumber baik internal maupun ekternal (verifikasi), melakukan interpretasi, analisis sampai menemukan fakta (validasi) yang akan disajikan dalam karya tulis sejarah atau dalam ilmu sejarah disebut historigrafi (Kuntowijoyo 1995:28). Menurut Gottschalk (1985, 28), metode sejarah adalah proses menguji dan menganalisis secara kritis rekaman peristiwa yang terjadi di masa lampau. Dengan demikian, tahapan kerja riset seperti itu memungkinkan sejarah memberi kontribusi pada ilmu-ilmu lain seperti sosiologi, psikologi, ekonomi, politik, sastra, dan sejenisnya khususnya pada aspek perubahan dan kesinambungan. Sejarah dengan cakupan spasial dan waktunya yang ketat dapat membaca perubahan dalam dimensi ruang dan waktu. Pengaruh politik dan ekonomi dalam perkembangan dua kota di Sulawesi Tenggara, Baubau dan Kendari, dapat dibaca dalam konteks itu, karena sejarah kedua kota berkembang pada era di mana teknologi informasi dan aksesibilitas belum memadai. Demikian pula dari sisi anggaran dan infrastruktur pada periode terjadinya peristiwa, masih jauh dari kata ideal.

\section{HASIL DAN PEMBAHASAN}

\section{Geografi dan Ekologi Kota Baubau dan Kendari}

Dalam mengkaji sebuah peristiwa dalam studi sejarah, aspek ruang menjadi hal yang mutlak dihadirkan, meskipun dalam perkembangan mutakhir, detail geografis bisa dengan mudah dapat dicari melalui Google Maps atau Google Earth di mana komputer berbasis Windows atau Android terhubung dengan internet. Keuntungan menghadirkan ruang penelitian adalah lebih detail daripada berbasis aplikasi, karena aplikasi meskipun berbasis satelit, detail atas ruang dari peristiwa yang diteliti tidak dapat dihadirkan. Atas alasan itu, kajian dari BPS, Dinas Topografi, BPN, dan kesaksian penduduk lokal lebih detail dan menguntungkan dari aplikasi yang disebut di atas.

Secara geografis, Kota Baubau dan Kendari terletak di ruang yang berbeda. Kota Baubau terletak di pulau Buton tepatnya di sisi darat Teluk Baubau atau di ujung selatan Selat Buton. Kota Kendari terletak di Teluk Kendari. Teluk ini merupakan salah satu ruang berlabuh paling aman dari gangguan 
badai di sisi barat Laut Banda. Ruang teluk yang memadai dan ruang masuk ke teluk yang tidak terlalu lebar dan dikelilingi oleh perbukitan, maka teluk terlindung dari berbagai gangguan badai. Teluk Kendari dipopulerkan oleh Vosmaer. J. N. Vosmaer menerbitkan tulisannya pada tahun 1839 tentang Teluk Kendari dan menamakannya dengan Vosmaer's Bay (Vosmaer 1839).

Penamaan itu tidak terlepas dari kerja keras Vosmaer memberi identitas kepada Teluk Kendari. Identitas yang disematkan oleh Vosmaer adalah pos militer dan kota pelabuhan. Dengan dua ciri khas itu, Kendari sedang memakai "baju" Eropa, artinya ciri sebagai kota Eropa atau dalam sejarah Indonesia disebut sebagai kota kolonial. Tata kota yang ditandai dengan penataan pemukiman dan jaringan jalan dibuat dengan rapi dan mudah diakses. Dengan demikian, ciri umum kota kolonial berlaku di Kendari. Bangunan khas Eropa dengan tembok tebal dan gaya arsitekturnya menghiasi Kota Kendari di sekitar pelabuhan. Demikian juga bangunan gereja yang berciri khas Eropa tampak jelas hadir di dalam ruang Kota Kendari.

Hal yang sama juga terjadi di Kota Baubau. Kota ini lebih dulu populer dibanding Kota Kendari. Baubau sebelum abad XIX masih dikenal sebagai Buton, yang lokasinya sangat dekat dengan pusat kekuasaan Kerajaan Buton. Dalam catatan sejarah, Buton (kini Baubau) telah berhubungan secara politik dengan VOC pada abad XVI sampai akhir abad XVII, kemudian dengan kolonial Belanda hingga berakhir pada tahun 1942. Hubungan yang panjang itu telah memberi ciri kolonial pada Kota Baubau. Perumahan, penjara, gereja, dan bangunan dalam Kota Baubau mencerminkan ciri bangunan di kota-kota kolonial. Dengan ciri itu, dapat dikatakan bahwa Kota Baubau telah diwarnai oleh orang-orang Eropa, khususnya Belanda dalam periode yang panjang.

Kota Baubau tumbuh menjadi kota pelabuhan dan sebagai salah satu pusat perdagangan yang ramai, sehingga fasilitas kota seperti penyewaan rumah, penyediaan listrik, instalasi air minum, dan pos dan perkapalan berkembang di Kota Baubau. Antara Kota Baubau dan Kendari, ekologi kotanya berawa, sehingga penduduknya rentan diserang penyakit, khususnya disentri dan malaria. Ekologi kota yang tanahnya terdiri dari rawa, maka langkah untuk pencegahan wabah adalah dengan melakukan pengeringan rawa melalui penimbunan dengan tanah atau batu, dan melakukan penataan lingkungan dan saluran air yang lancar agar tidak menimbulkan genangan. Hal demikian telah dilakukan di dua kota, sehingga penderita penyakit lebih terkendali.

\section{Perspektif Sejarah Politik dan Ekonomi Kota}

Sejarah politik di dua kota, Kendari dan Buton (kini Baubau), dapat dilacak sejak berdirinya institusi setingkat kerajaan di wilayah itu. Di Pulau Buton terdapat lembaga politik yang disebut kerajaan, yakni Kerajaan Buton, yang hingga kini jejaknya masih bisa disaksikan seperti peninggalannya dalam bentuk rumah lama, baruga, masjid kuno, dan benteng yang melindungi permukiman para bangsawan di kompleks Keraton Buton. Kerajaan Buton menurut catatan sejarah berdiri sejak abad XV. Kerajaan ini hingga kini dikenal dengan Kesultanan Buton (Zahari 1977).

Di Kendari, kerajaan yang ada dalam catatan sejarah adalah Laiwoei. Kerajaan ini baru dikenal dan ada dalam arsip tetulis pemerintah sejak abad XIX. Wilayahnya agak ke pedalaman, bukan di lokasi Kota Kendari saat ini. Belanda mengidentifikasi bahwa Kerajaan Laiwoei berbasis agraris. Para penguasa Laiwoei melakukan perdagangan di Teluk Kendari ketika teluk itu ramai dengan pedagang Bugis, Bajo, Arab, dan Belanda. J. N. Vosmaer ikut memberi kontribusinya dalam membangun kota Kendari ketika ia membangun pos militer, pelabuhan, dan menjadikan kawasan itu sebagai pos pantau dalam pengamanan aktivitas ekonomi Belanda (Vosmaer 1839; Noor 2019) dari gangguan bajak laut yang beroperasi di sisi Barat Laut Banda (Velthoen 2005; 2010:200-221; Rabani 2019:4752). 
Pada akhir abad XIX sampai awal abad XX, suasana politik di dua kota selalu menghangat. Laporan pemerintah kolonial setiap tahunnya (koloniaal verslag dari tahun 1850 sampai 1930) memuat adanya gangguan keamanan penduduk dan pemerintah di kedua wilayah. Beberapa oknum dari bangsawan Buton misalnya menentang pemungutan pajak yang dilakukan pemerintah Belanda. Konfrontasi pun tidak terhindarkan ketika pemerintah Belanda memaksa penduduk untuk pembayaran pajak. Dalam sejarah Buton, perlawanan lokal terhadap pemerintah dilakukan oleh La Ode Bosa (Rabani 2010b:14-21).

Selama masa penjajahan Jepang, awal kemerdekaan, hingga 1960-an, gerakan politik yang mengganggu ketertiban tidak pernah berhenti di kedua wilayah. Pemaksaan dan kerja rodi yang terapkan pada masa Jepang telah menimbulkan keresahan dan "penderitaan" psikologis pada masyarakat di kedua kota, Baubau dan Kendari. Di Kendari, penduduk dipaksa menyerahkan beras dan bahan pangan lainnya. Selain itu, mereka juga dipaksa bekerja untuk mengangkut hasil produksi nikel yang ditinggalkan Belanda. Di Kota Baubau, sebagian penduduk dijadikan tentara dan perahunya menjadi sarana mobilitas tentara. Selain itu, mereka mengangkut sisa produksi aspal ke kota lain untuk dijual atau digunakan untuk pengerasan jalan guna mendukung mobilitas tentara Jepang (Sangaji 2002; Rabani 2009:630-640).

Kekacauan politik pada pascaperiode awal kemerdekaan hingga 1960-an yang membawa implikasi pada dua kota di Sulawesi Tenggara sebenarnya dipicu dari luar wilayah. Catatan sejarah menunjukkan bahwa dua kota, Kendari dan Baubau, berada dalam Negara Indonesia Timur yang dibentuk Van Mook. Posisi itu berlangsung hingga tahun 1950. Status Kota Baubau pada saat itu adalah daerah swapraja, sebagaimana tercantum dalam lembaran negara Indonesia Timur. Lembaran negara itu menyatakan bahwa semua daerah dengan status 6nderafdeeling diubah menjadi neoswapraja. Wilayah neo-swapraja meliputi Buton dengan ibukota Baubau, Raha, Kendari, dan Mekonga (kini Kolaka). Semua daerah itu tergabung di dalam Federasi Sulawesi Selatan sebagaimana termuat dalam Ordonasi Indonesia 1946 (Ordonantie Indonesia no.143 tahun 1946).

Gerakan DI/TII atau menurut istilah Barbara S. Harvey sebagai pemberontakan setengah hati yang terjadi di Sulawesi Selatan dan juga meluas hingga ke Sulawesi Tenggara (Harvey 1987b). Dua kota yang terdampak dari gerakan/pemberotankan ini di Sulawesi Tenggara adalah Kota Baubau dan Kendari. Kedua kota menerima limpahan penduduk pedalaman yang sebelumnya tinggal di desa-desa sekitar kota. Penduduk itu pada umumnya adalah petani. Pada masa pemberontakan itu, mereka menjadi korban perampasan berupa harta, hasil pertanian, dan juga disandera. Penduduk pedalaman dan yang disandera oleh para pemberontak yang berhasil dibebaskan oleh tentara, dibawa ke kota untuk didata dan menerima hak-haknya sebagai pengungsi. Hidup di dalam tenda, tinggal di kota, dan memperoleh jaminan keamanan dan makanan dari pemerintah. Dampak tersebut akan diuraikan tersendiri yang membahas dampak kekacauan politik bagi perkembangan dua kota di Sulawesi Tenggara, Baubau dan Kendari.

Upaya pemulihan keamanan dan ketertiban terus dilakukan. Akan tetapi, peristiwa politik lain kembali hadir yakni tuntutan masyarakat untuk membentuk Provinsi Sulawesi Timur yang wilayahnya adalah bekas Afdeeling Oost Celebes yang dibentuk pemerintah Belanda pada tahun 1912. Saat tuntutan itu diperjuangkan, dua kota yang diteliti masih berada pada wilayah Provinsi Sulawesi Tenggara dengan ibukota di Baubau. Masyarakat Sulawesi Selatan Tenggara saat itu mengusulkan nama provinsi dengan Sulawesi Timur karena ikatan sejarah dan dasar historinsya telah ada. Setelah melalui proses panjang di mana beberapa pertemuan dilakukan dengan Kementerian Dalam Negeri dan Otonomi Daerah, nama Sulawesi Timur benar-benar tidak pernah lahir seperti masa Hindia Belanda. Salah satu perwakilan Sulawesi Timur saat itu di Kemendagri dan Otonomi 
Daerah adalah La Ode Manarfa, yang menjadi pejabat pemerintah Sulawesi Selatan Tenggara. Ibukota yang diusulkan saat itu adalah Baubau dengan alasan kesiapan infrastruktur, sumber daya manusia, dan sarana transportasi yang memadai untuk perhubungan dan mobilitas.

Hasil dari perjuangan otonomi daerah itu adalah lahirnya Provinsi Sulawesi Tenggara pada Tahun 1964 dengan Ibukota Kendari. Hasil itu membawa dua konsekuensi, pertama adalah hasil yang dicapai tidak sesuai dengan perjuangan awal, dan kedua, mengabaikan posisi historis Baubau yang telah berkali-kali menjadi ibukota, seperti ibukota Onderafdeling Buton, Afdeeling Sulawesi Timur, dan Afdeeling Buton en Laiwoei (Kendari). Kota Kendari telah mengalami gejala kekotaan dengan ciri kota kolonial sejak tahun 1830-an. Kota Kendari pernah menjadi ibukota Onderafdeeling Laiwoi. Dilihat dari sejarah tersebut, sebenarnya Baubau "sangat" layak menjadi Ibukota Sulawesi Tenggara, akan tetapi karena telah menjadi keputusan politik, harus menerima kenyataan atas terpilihnya Kota Kendari sebagai ibukota (Rabani 2016).

Beberapa sebab terpilihnya Kota Kendari sebagai Ibukota Provinsi Sulawesi Tenggara di antaranya kalah jumlah suara pada saat pemilihan untuk penentuan ibukota. Selain itu, terjadi malbirokrasi di mana ada dinas di Kota Baubau yang mengajukan anggaran dua versi dan yang mengajukan dua orang, sehingga terjadi dualisme dalam satu dinas. Akibatnya, kekacauan dalam sistem birokrasi dan tata pemerintahan sangat mungkin terjadi jika Kota Baubau menjadi ibukota provinsi. Oleh karena itu, Mendagri dan Otonomi Daerah dalam keputusannya mengesahkan Kota Kendari sebagai Ibukota Provinsi Sulawesi Tenggara. Reaksi masyarakat Buton atas keputusan itu kecewa, tetapi tetap harus menerima kenyataan yang ada. Lalu, apakah dengan tidak menjadi Ibukota Sulawesi Tenggara, kota Baubau mengalami kemunduran?

Untuk menjawab pertanyaan di atas, kenyataan sejarah yang telah lama terjadi di Kota Baubau perlu dihadirkan. Pertama, Baubau adalah teluk dan terhubung dengan Selat Buton untuk pelayaran dari dan ke pusat produksi rempah-rempah Maluku melalui sisi barat Laut Banda. Teluk ini menjadi ruang yang aman untuk tempat berlabuh bagi kapal-kapal dan perahu yang melintasi sisi barat Laut Banda. Artinya, Baubau telah menjadi salah satu pusat jaringan perdagangan internasional (center of network of trade) (Rabani 2010a). John Pieter Coen, Jenderal VOC yang bekerja sama dengan Kesultanan Buton, telah memilih Buton (Baubau) sebagai salah satu tempat kedudukan birokrasinya. VOC pun melakukan perjanjian abadi untuk saling melindungi dari berbagai gangguan (Schoorl 1991:21-61). Hubungan politik berlanjut antara VOC dan Kesultanan Buton yang berpusat di Baubau dengan melakukan aliansi pada perang melawan Makassar bersama-sama dengan Ternate dan Bone. Aliansi itu dimenangkan VOC dan sekutunya. Akibatnya, Makassar harus takluk dan merelakan pulau-pulau yang dikuasainya kembali ke tengan kekuasaan Ternate dan Buton. Makassar harus menandatangani perjanjian Bungaya 1667. Selain itu, Makassar diharuskan membayar pampasan perang dan mengakui VOC sebagai penguasa tertinggi (Stapel, 1922; Andaya 2004).

Pada perkembangan selanjutnya, infrastruktur kota telah mendapat perbaikan. Catatan sejarah perbaikan kota itu dilakukan atas komando van Hasselt, seorang warga Sumatra Utara. Van Hasselt melakukan perbaikan ekologi dan lanskap kota dengan tujuan utama perbaikan tata kota dan lingkungan guna menurunkan penderita penyakit malaria di Kota Baubau pada tahun 1922 dengan merujuk pada pola yang sama seperti yang dilakukan di Kota Sibolga (Vogel 1916). Proyek perbaikan lingkungan kota ini melibatkan penduduk Baubau dan sekitarnya yang didorong oleh lahirnya kesadaran masyarakat untuk memberantas malaria di Baubau dan sekitarnya. Dampak dari perbaikan ini sangat signifikan menurunkan penderta malaria, dibanding periode yang sama dengan tahun sebelumnya. Selain itu, tata kota menjadi teratur, jaringan jalan lebih baik, lingkungan kota tidak lagi menjadi sarang nyamuk malaria, dan lingkungan lebih bersih (Staten-Generaal 1924). 
Pada tahun 1923, pemerintah Belanda melakukan penyelidikan pada deposit aspal di Pasar Wajo. Pasar Wajo adalah wilayah yang hanya berjarak sekitar $40 \mathrm{~km}$ dari Kota Baubau. Dalam laporannya, sebagaimana dimuat dalam Kolonial Verslag 1924, disebutkan bahwa aspal Buton memiliki masa depan yang baik, sehingga Buton harus bersiap untuk menerima para pedagang dari berbagai negara dan harus menyiapkan infrastruktur pelabuhan bagi kapal-kapal yang akan mengangkut aspal dari berbagai negara. Pasar Wajo didatangi oleh kapal uap yang mengangkut aspal. Antara perbaikan kota, pelabuhan, pemberantasan penyakit, dan rencana eksploitasi aspal seperti berkait dengan politik kolonial, yakni politik perbaikan kota dalam rangka menyambut investor. Perbaikan kota pada tahun 1922 dan penemuan aspal pada tahun berikutnya (1923) adalah dua hal yang paralel kerena kaitan keduanya sangat dekat. Hanya saja, tidak ada dokumen yang menyatakan secara detail tentang relasi keduanya. Politik ekonomi yang menyertai Pax-Neerlandica menguatkan dugaan itu (Haeruddin 2013), karena sejak 1905 ketika Kesultanan Buton mengakui Pemerintahan Belanda sebagai penguasa tertinggi, maka eksplorasi, penelitian, eksploitasi atas sumber-sumber ekonomi di Sulawesi Tenggara giat dilakukan, termasuk pengiriman para misionaris (Klift 1933).

Selain komoditas pertambangan, Baubau (Buton) juga didukung oleh sarana transportasinya yang memadai. Para pelayar dan pelaut Buton populer dalam aspek pengangkutan, pelayaran dan perdagangan (Hadara 1987). Artinya, tradisi maritim dengan fokus ekonomi, maka masyarakat Buton tidak terpengaruh oleh perubahan status administratif ibukota. Masyarakat Buton pada periode pascakemerdekaan masih melanjutkan aktivitas ekonomi lamanya, yakni pertanian, pelayaran, perdagangan, dan bekerja di pertambangan aspal di Pasar Wajo, Lawele, dan Wariti (Bothe 1928). Perdagangan antarpulau dan pengangkutan komoditas dari pusat-pusat produksi ke pusat-pusat industri seperti Makassar dan Surabaya.

Dengan realitas itu, maka Kota Baubau tetap berkembang, meskipun tidak menjadi pusat birokrasi setingkat propinsi. Perkembangan ekonomi yang telah berlangsung lama yang ditunjang oleh infrastruktur pengangkutan untuk perdagangan dan mobilitas antarpulau telah membuat posisi Kota Baubau tetap bergeliat. Lokasi dan kondisi alamnya yang mendukung keamanan dan kenyamanan sebagai tempat berlabuh membuat Kota Baubau terus didatangi oleh para pedagang. Oleh karena itu, Kota Baubau terus berkembang dan menjadi salah satu kota pelabuhan penting di Sulawesi Tenggara. Baubau juga telah menjadi pusat "transit" komoditas pertanian dan kelautan. Posisi ini telah mendorong penduduk sekitarnya bermigrasi ke Kota Baubau (Rabani 2005c).

Laporan pemerintah Belanda sebelum penemuan kayu Jati (1903) dan aspal (1923), Buton adalah daerah yang miskin sumber daya. Berbeda dengan Laiwoei (Kota Kendari) yang ramai dengan perdagangan ikan kering, beras, teripang, dan mutiara. Komoditas itu dimonopoli oleh para pedagang Cina. Orang-orang Cina menguasai perdagangan produk laut di teluk Kendari dengan mempekerjakan orang-orang Bajo untuk melakukan pencarian dan penyelaman mutiara, lola, dan teripang si pulau-pulau sekitar Buton, Kendari, dan Bungku. Selain orang Cina, orang-orang Bugis juga menjadi pedagang produk laut dari teluk Kendari dan Buton. Orang-orang Bugis bahkan mencari teripang hingga ke Australia utara untuk dijual kepada perdagang Cina di Singapura (Vosmaer 1839). Ekonomi kota Baubau selain ditunjang oleh komoditas pertambangan, juga didorong oleh produk kehutanan dan budidaya, seperti mutiara dan pembukaan perkebunan kelapa (Broersma 1931:1041-1042).

\section{Pemilu 1955, Elite Lokal, dan Memperjuangkan Otonomi}

Periode akhir dari Negara Indonesia Timur (NIT) dan Republik Indonesia Serikat (RIS) ditandai dengan integrasi wilayahnya ke dalam Negara Kesatuan Republik Indonesia (NKRI). Integrasi itu membawa beberapa perubahan, di antaranya pada penamaan daerah. Nama Afdeeling diganti dengan 
daerah, sehingga Afdeeling menjadi Pemerintah Daerah, seperti Sulawesi Selatan yang dikepalai oleh gubernur. Perubahan lain yang terjadi adalah tugas controleur di bekas onderafdeeling digantikan oleh Pamong Praja yang saat itu disebut dengan Kepala Pemerintahan Negeri (KPN). Onderafdeeling selanjutnya disebut dengan daerah kawedanan. Untuk Afdeeling Boeton en Laiwoei menjadi Pemerintah Daerah Buton dan Laiwui. Situasi itu terus berlanjut hingga masa-masa kemudian.

Faktor politik sangat dominan memengaruhi perkembangan dan perluasan Kota Baubau. Kota itu mengalami perkembangan berarti ketika masih di bawah kekuasaan pemerintah Hindia Belanda. Pada tahun 1922, kota Baubau mengalami perluasan dan perbaikan secara ekologis. Saluran air diperbaiki dan diperlancar dengan pembuatan gorong-gorong yang terhubung langsung dengan laut. Perbaikan ini dilakukan sebagai upaya pemberantasan penyakit Malaria yang selalu mengancam kesehatan warga Kota Baubau. Perbaikan ekologi kota Baubau di lakukan pemerintah bersama warga kota di bawah komando van Hasselt (Staten-Generaal 1923, Hofdstuck J:16). Desain dan metode pengerjaan perbaikan ekologi kota seluruhnya mencontoh perbaikan ekologi Kota Sibolga di Pantai Barat Sumatra di bawah komando Vogel (1916:62-98).

Kota Baubau mengalami kemunduran perkembangan dan pergeseran ketika kota itu diwarnai oleh perubahan politik dan dikontrol kekuasaan yang kuat oleh pemerintah Indonesia. Lemahnya kontrol dan melemahnya kekuasaan sultan pada pascakemerdekaan serta banyaknya konflik yang mewarnai dinamika internal kota telah menghambat laju perkembangan fisik kota. Hanya saja di sisi lain, kota menjadi lebih hidup dan suasana kota makin terasa dengan munculnya gairah demokrasi dalam kota. Tokoh-tokoh lokal mulai muncul untuk mencoba merespons perubahan situasi di dalam kota yang diwarnai oleh arus kebebasan termasuk mempertanyakan kelangsungan dan pergantian kekuasaan untuk mengontrol masyarakatnya pada tingkat lokal.

Sebelum pemilu 1955, status Kota Baubau adalah sebagai Ibukota Kabupaten Sulawesi Tenggara. Hal ini sesuai Peraturan Pemerintah no. 34 tahun 1952. Kewenangan yang dimiliki pemerintah kota adalah mengurus hal-hal seperti urusan umum (tata usaha) sendiri, urusan pemerintahan umum, urusan pertanian, perikanan, dan kehutanan, urasan pengairan, jalan, dan jembatan, urusan ekonomi dan lainnya seperti kehewanan, urusan pendidikan, pengajaran dan kebudayaan, dan urusan kesehatan masyarakat.

Partai politik yang tercatat secara resmi pada pemilu 1955 di Kabupaten Sulawesi Tenggara adalah Masyumi, PNI, PSII, PSI, Parkindo, Partai Katholik, Partai Kedaulatan Rakyat, Partai Buruh, dan Permai. Anggota dari beberapa partai secara rinci dapat di lihat pada tabel berikut, lengkap dengan jumlah anggota dan tahun berdirinya.

Tabel 1. Data Parpol pada Pemilu 1955 di Kota Baubau

\begin{tabular}{cccc}
\hline Nama Partai & Jumlah Anggota & Tahun Berdiri & Ket \\
\hline PSII & 71 & 1946 & \\
Parkindo & 50 & 1952 & (Muna) \\
Partai Katholik & 500 & - & \\
PNI & 50 & 1951 & \\
PSI & 50 & 1951 & \\
Permai & 190 & 1951 & \\
Masyumi & - & - & \\
Partai Buruh & 252 & - &
\end{tabular}

Sumber: diolah dari: M. Arsyad Talha, Kabupaten Sulawesi Tenggara ke Status Propinsi (Kendari: Biro Hukum Pemda Tk. I Sultra, 1982), hlm. 142. 
Pengalaman berdemokrasi pada awal kemerdekaan menarik untuk ditelaah lebih jauh. Pada pemilu I anggota partai politik berasal dari kalangan pegawai negeri, pegawai daerah, jawatan buruh, guru SR, kepala distrik, dan kepala kampung, dan buruh perusahaan. Ada juga yang berasal dari pejabat pemerintah daerah, termasuk anggota Dewan Perwakilan Rakyat Daerah Sementara. Anggota DPRDS berjumlah 23 orang (PP no. 34 tahun 1952, pasal 3). Data Tabel 1 di atas menunjukkan bahwa partai yang paling banyak pengikutnya adalah Masyumi dan PNI. Partai itu diminati pemilih karena ketokohan dalam partai yang memiliki pendidikan yang baik, semua tokoh partai berasal dari kalangan berpendidikan.

Menarik mencermati keanggotaan partai pada pemilu 1955. Dari sisi anggota jelas bahwa masyarakat dan rakyat diberi kebebasan seluas-luasnya untuk menjalankan hak dan kewajibannya dalam berpolitik. Di samping itu, realitas bahwa elit partai yang pendidikan menjadi salah satu tolok ukur warga negara memilih partai patut diangkat ke permukaan. Hal ini penting bahwa warga negara pada Pemilu I menggunakan pilihan yang sangat rasional. Perlu diketahui bahwa Pemilu I tahun1955 dilaksanakan 2 kali, yakni tanggal 29 september untuk memilih anggota DPR dan tanggal 15 Desember untuk memilih anggota konstituante (Feith 1999).

Sebagai pemilu pertama dan semuanya masih pada tahap belajar berdemokrasi, maka peraturan masih bersandar pada kementerian dalam negeri dan otonomi daerah. Peraturan itu di antaranya adalah pembagian kursi parlemen yang didasarkan pada peraturan Mendagri, termasuk pada level daerah. Sebagai gambaran, pembagian kursi di DPRDS harus berdasarkan peraturan Menteri Dalam Negeri No. 7 tahun 1952 jo. No.11 tahun 1953. Peraturan itu menetapkan bahwa komposisi DPRDS Sulawesi Tenggara jumlahnya 16 orang yang berasal dari partai politik dan sisanya diangkat oleh pemerintah. Untuk melaksanakan PP itu, maka pada 20 Oktober 1952 antara pemerintah dan parpol mengadakan pertemuan di kota Raha. Pertemuan itu dihadiri Mr. Pabelu (Masyumi), Ch. Pingak (PNI), A. Gani (PSII), La Ado (PSI), Toboeloe (Partai Buruh), Risamena (Parkindo), dan Ambo Mase (PIR). Dari pihak pemerintah, hadir Gubernur Soediro dan Bupati Sulawesi Tenggara. Pertemuan itu menetapkan 6 kursi untuk Masyumi, 5 kursi untuk PNI, dan 1 kursi untuk partai PSII, PSI, Partai Buruh, Parkindo, dan PIR. Lebih jelasnya pembagian kursi DPRDS Sulawesi Tenggara, dapat dilihat pada tabel 2. Ketetapan itu dilegalkan dengan Keputusan Mendagri tanggal 17 April No. Des.2/5/49.

Tabel 2. Komposisi Perolehan Kursi DPRDS Sulawesi Tenggara

\begin{tabular}{clcc}
\hline No & \multicolumn{1}{c}{ Nama Wakil } & Jumlah Kursi & Nama Partai \\
\hline 1 & La Ato & & \\
2 & Andi Abdul Kadir & 6 & Masyumi \\
3 & Ma'mun & & \\
4 & Abd. Rahim & & \\
5 & Muh. Ali Silondae & 1 & PSII \\
6 & H. Abd. Razak & & \\
\hline 7 & Abd. Gani Masasan & 5 & PNI \\
\hline 8 & La Ode Abd. Halim & & \\
9 & La Madjoe & & PIR \\
10 & Julius Rumamby & 1 & Parkindo \\
11 & F.H. Lenohingide & 1 & Partai Buruh \\
12 & Ch. Pingak & 1 & PSI \\
\hline 13 & Machmud Bante & 1 & - \\
14 & MM. Risamane & 16 & \\
15 & Toeboeloe & La Ado &
\end{tabular}


Sesuai peraturan, anggota DPRDS Sulawesi Tenggara berjumlah 23 orang. Anggota yang berasal dari partai peserta pemilu adalah 16 orang/kursi dan sisanya atau 7 kursi berasal dari pertimbangan dan penetapan pemerintah. Tujuh (7) orang anggota/kursi yang diangkat dari pertimbangan pemerintah adalah La Ode Muh. Shalihi, Nona Halipah, Ambo Masse, Abdul Wahab, Moezoeni, dan S. Joesoef (SK Mendagri no.2/2/42 tanggal, 19 Februari 1953). Setelah penetapan itu, ditetapkan juga wilayah kerja dari anggota DPRDS. Penetapan wilayah kerja itu adalah seperti berikut ini. Kota Baubau (Buton) 9 kursi, Muna, 6 kursi, Kendari 6 Kursi, dan Kolaka 2 kursi. Sedangkan ketua DPRDS berdasarkan rapat pemilihan tahun 1953, yang terpilih sebagai ketua adalah Ch. Pingak (PNI) dan wakilnya La Ato dari Masyumi.

Jalannya sidang anggota DPRDS penuh dinamika dan juga sejumlah kesulitan. Agenda dan urusan yang padat, tidak tersedinya infrastrukutr seperti rumah dinas, serta sulitnya perhubungan telah menjadi tantangan tersendiri. Bahkan ketua dewan harus mengundurkan diri, karena alasan perhubungan dan jarak antara lokasi tugas dengan ibukota yang jauh. Sejarah mencatat bahwa Ch. Pingak, ketua DPRDS mengundurkan diri sebagai ketua pada sidang kedua pada 14-21 Juli 1953 dengan alasan perhubungan sulit dan tempat tinggalnya jauh dari pusat kota Baubau, yakni di Kolaka, sehingga tidak bisa menjalankan tugasnya secara optimal. Atas alasan itu, maka sidang penggantian ketua kembali dilaksanakan di gedung sekolah Cina, kota Baubau pada tanggal 21 Juli 1953. Sidang itu menutuskan pengganti Ch. Pingak adalah La Ado (PSI). Gedung sekolah Cina di kota Baubau seperti tampak dalam foto berikut ini. Praktis tidak mengalami perubahan dari sisi arsitekturnya.

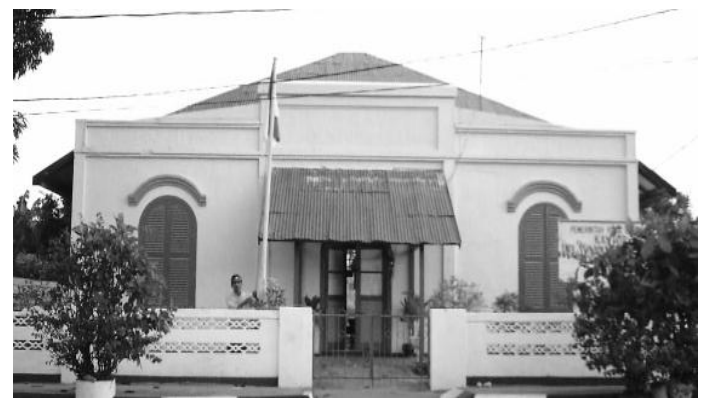

Gambar 1. Bekas Sekolah Tionghoa di Kota Baubau (Sumber: koleksi penulis, 2004)

Sidang selanjutnya juga dilakukan di gedung sekolah Tionghoa Kota Baubau pada tanggal 20-23 Oktober 1953. Sidang menetapkan mengisi posisi wakil ketua dan diganti dengan Ma'mun (Masyumi). Selain itu, disepakati peninjauan kembali peraturan tentang uang sidang, uang jalan, uang menginap, dan uang representasi anggota DPDS, ketua/wakil ketua, dan anggota DPDS untuk disesuaikan dengan Instruksi Menteri Dalam Negeri no. Des. 18/9/23 tanggal 13 Mei 1953. Penetapan Anggaran dan Belanja Daerah untuk tahun 1954 sebesar Rp.12.513.222 (Talha 1982:156157).

Dinamika lain dari sejarah persidangan DPRDS adalah lokasi persidangan. Pada tanggal sidang anggota DPRDS dilakukan pada 18-23 Januari 1954 di Kota Kendari. Hasil yang dicapai dalam persidangan di Kendari adalah penetapan Abdul Rahim menjadi anggota DPD menggantikan Kanggoasa yang tidak lagi bersedia karena alasan isntansi kerjanya sebagai wedana militer tidak memperoleh ijin. Hasil lainnya adalah Perda tentang istirahat karena pegawai pemerintah yang hamil, kerja dan pemberian uang lembur, pemberian libur dalam negeri, pemungutan pajak anjing, daftar susunan dan kenaikan pangkat, cara membuat dan mengundangkan peraturan-peraturan daerah, daftar pernyataan kecakapan pegawai, pensiunan pegawai daerah, pemberian uang duka kepada janda 
dan ahli waris pegawai yang tewas dalam menjalankan tugas, pengangkatan pegawai daerah tetap, dan pemberian uang pensiun kepada janda dan tunjangan anak yatim pegawai negeri sipil (Arsip Daerah Kendari, Catatan hasil sidang DPRDS tahun 1954). Catatan lain DPRDS pada sidang yang sama adalah catatan untuk pemerintah daerah, yakni sebegai berikut:

1. meminta didirikan asrama polisi yang permanen untuk kepolisian negara di Baubau dan Raha.

2. Perbaikan status kepala distrik agar kedudukannya sama dengan mantri polisi muda.

3. Perbaikan nasib kepala kampung di seluruh Sulawesi Tenggara.

4. Sekolah Rakyat dan Lanjutan diperbanyak.

5. Menempatkan tenaga dokter pemerintah di setiap rumah sakit.

6. Memperbanyak poliklinik pada setiap rumah sakit.

7. Pembayaran pensiun tidak diperlambat.

8. Perumahan rakyat harus mendapat perhatian dan segera diadakan Cabang Jawatan Perumahan Rakyat di Sulawesi Tenggara.

9. Tidak menyetujui status bekas daerah onderafdeling sama dengan daerah setingkat kecamatan. (Arsip Daerah Kendari, Catatan hasil sidang DPRDS tahun 1954a).

Salah satu tokoh yang tercatat namanya dalam sejarah politik dan memori masyarakat Kota Baubau adalah La Ode Hadi. Tokoh ini populer karena mencalonkan diri bukan dari partai politik, melainkan atas nama pribadi. La Ode Hadi mendapat dukungan luas dari masyarakat Sulawesi Tenggara. Pada pemilu 1955, perolehan suara La Ode Hadi sebanyak 33.269 suara, sangat signifikan untuk calon independen (Feith 1999:93-102). Perolehan suara yang mencapai puluhan ribu itu tidak terlepas dari pribadinya yang berpendidikan dan dikenal baik oleh masyarakat. Masyarakat memilihnya bukan karena berasal dari garis keturunan, yakni putra dari Sultan Buton (La Ode Muh. Falihi), tetapi karena perangainya yang baik di mata masyarakat. Meskipun banyak mendapat dukungan masyarakat Sulawesi Tenggara, La Ode Hadi tidak serta-merta menjadi Bupati Sulawesi Tenggara saat itu. Hal itu terjadi karena dinamika politik yang berkembang, salah satunya adalah adanya pemilihan Gubernur Sulawesi Tenggara. Pada saat itu, J. Wajong menjadi gubernur dan menyiapkan pemilihan Gubernur Sulawesi Tenggara berikutnya sejak 1958.

Pada tahun 1950-an, dinamika politik terus terjadi, salah satunya adalah menguatnya tuntutan daerah untuk melepaskan diri dari Propinsi Sulawesi Selatan-Tenggara. Realisasi pemekaran Sulawesi Tenggara menjadi daerah otonom ternyata membawa persoalan baru dalam birokrasi pemerintahan. Hal ini terjadi karena sumber daya manusia yang berasal dari Sulawesi Tenggara yang belum memadai, sehingga posisi birokrasi banyak diisi oleh orang-orang berpendidikan dan berasal dari Sulawesi Selatan. Kondisi itu menimbulkan suasana yang tidak nyaman, khusunya bagi warga lokal. Bibit memperjuangkan daerah otonomi tahun 1950-an untuk membentuk Sulawesi Timur mengemuka, khususnya di kota Baubau.

Pada tanggal 17 Februari 1957 dilaksanakan musyawarah di Makassar yang dihadiri oleh para pemuda yang berasal dari Baubau, Banggai, Luwuk, Bungku, Mori, Kolaka, dan Muna. Pertemuan berlangsung di ruang belajar SMEP, Jl. Bawakaraeng no. 39, Makassar dengan agenda utama membentuk Badan Penuntut Perjuangan Pembentukan Daerah Tingkat I Sulawesi Timur. Badan ini anggotanya dari para pemuda di semua daerah itu dan diketuai oleh Nitung yang berasal dari Luwuk (Banggai). Peserta musyawarah menyetujui dan memberikan mandat kepada Badan Penuntut untuk pembentukan Propinsi Sulawesi Timur baik secara tertulis maupun dengan jalan perundingan (Duke 1997a:74-79; DPRD 1977:35).

Pada tahun 1958, orang Moronene (Kolaka) ingin melepaskan diri dari Luwu. Mereka ingin bergabung dengan Kabupaten Sulawesi Tenggara. Usul ini baru disetujui oleh Dewan Tingkat II 
Mekongga pada tanggal 5 Mei 1960. yang ditandai dengan pemilihan anggota Dewan yang duduk dalam Dewan Tingkat II Mekongga (Surat Ketua Dewan Pleno Persiapan Darah Tingkat II Mekongga No. 001/D.P./ 59, Agenda No. 74/810/59, tanggal 12 Mei 1959. Koleksi Arsip Daerah Kendari). Menguatnya tuntutan untuk pembentukan Sulawesi Timur dan adanya keinginan dari orang-orang Morone telah memperkuat perjuangan otonomi daerah bagi Sulawesi Timur.

Tuntutan yang terus dilakukan memperoleh hasil ketika Menteri Dalam Negeri, Sanusi Harjadinata, menetapkan daerah itu sebagai daerah tingkat I dengan SK tanggal 27 Februari no. 20/2/1958. Kepala daerah ditentukan setelah mendengar pertimbangan dari Gubernur Sulawesi Selatan, G. S. S. J. Ratulangi. Masyarakat Sulawesi Tenggara saat itu mengusulkan La Ode Manarfa (Sultan Buton) untuk menjadi gubernur. Usul itu tidak disetujui dan Gubernur Sulawesi Selatan menunjuk J. Wajong sebagai gubernur transisi dan kemudian mempersiapkan pemilihan gubernur yang baru. Setelah J. Wajong sebagai gubernur ia digantikan oleh La Ode Hadi yang saat itu juga terpilih dalam pemilu 1955 sebagai anggota parlemen dan konstituante.

Undang-undang no. 29 tahun 1959 telah mengesahkan Sulawesi Tenggara berstatus provinsi dan sebagai daerah otonom dengan wilayah meliputi Buton, Kendari, Muna, dan Kolaka. Dengan terbentuknya daerah otonom baru tersebut, La Ode Manarfa yang merupakan Bupati Kabupaten Sulawesi Tenggara berakhir. Bersamaan dengan itu, maka Gubernur Sulawesi Selatan Andi Pangeran Petta Rani atas nama menteri dalam negeri melantik Bupati Kolaka, Jacob SilandoE, untuk pertama kalinya pada tanggal 29 Februari 1960 di gedung nasional Kolaka. Pada tanggal 1 Maret 1960 Bupati Buton La Ode Abd. Halim juga dilantik dan diambil sumpahnya di gedung DPRDS Baubau yang saat itu masih merupakan gedung DPRDS Sulawesi Tenggara. Sehari sesudahnya yakni tanggal 2 Maret 1960 La Ode Abdul Koedoes dilantik menjadi Bupati Raha di gedung Panti Pembangunan Raha. Dan pada tanggal 3 Maret 1960 Bupati Kendari Abdullah SilondaE dilantik di Kendari (Instruksi Menteri Dalam negeri No. 1/PD tanggal 29 September 1959 Lamp. B).

Pada tahun 1960, ketika penentuan Ibukota Provinsi Sulawesi Tenggara tarik-menarik kepentingan antara tokoh masyarakat lokal sangat terasa. Pemerintahan Swapraja Buton yang berkedudukan di Kota Baubau merasa mempunyai hak menjadi ibukota. Akan tetapi, realitasnya berbeda, kalah dalam pemilihan untuk penentuan ibukota baru, yakni Kendari. Komposisi keseluruhan suara yang ikut dalam pemilihan dan penentuan ibukota adalah sebagai berikut: Baubau (27 suara), Raha (15 suara), Kendari (15 suara), dan Kolaka (15 suara). Dengan komposisi itu, maka Kendari memperoleh suara terbanyak, yakni 45 suara, di mana hasil akumulasi dari seluruh perwakilan Kendari, Raha, dan Kolaka. Dengan hasil pemilihan itu, Kota Kendari ditetapkan sebagai Ibukota Provinsi Sulawesi Tenggara.

\section{Kekacauan Politik dan Implikasinya pada Perkembangan Kota Baubau dan Kendari}

Satu arsip yang meyakinkan penulis tentang adanya implikasi kekacauan politik di Sulawesi Tenggara pada perkembangan kota Baubau dan Kendari berasal dari kawat rahasia yang dikirim kepala Pemerintahan Negeri Kendari pada 23 November 1955. Kawat rahasia itu ditujukan kepada Djawatan Sosial Propinsi di Makassar. Pokok dari surat tersebut adalah mengenai penanganan pengungsi di Laiwoei (Kendari) selatan Roraya (Kawat Rahasia, Kepala Pemerintahan Negeri Laiwui Kendari, No. Pem 3/x/1/420, tanggal 23 November 1955).

Secara teoretis, kekacauan yang disebabkan oleh suatu peristiwa politik berimplikasi pada politik juga seperti jatuhnya korban di kalangan sipil, penggunaan kekuatan militer melalui operasi pemulihan keamanan, dan sebagainya. Akan tetapi, kekacauan politik sejauh ini tidak dilihat sebagai salah satu bagian dari sejarah yang ikut memberi kontribusi pada perkembangan atau kemunduran dari suatu 
kota. Dalam kasus, kota Baubau dan Kendari, misalnya, sebelum kekacauan sebagian penduduk wilayah itu masih bermukim di sekitar lahan pertanian mereka. Akan tetapi, kekacauan politik telah memaksa mereka untuk pindah ke kota dengan alasan keselamatan dari penculikan, pemaksaan, kekerasan, dan penyandraan oleh gerombolan DI/TII. Tentara Indonesia yang melakukan operasi pembebasan sandra harus membangun infrastruktur jalan, jembatan, dan mengakses sandra dari tangan gerombolan. Mereka yang berhasil dibebaskan, langsung dibawa ke kota Kendari. Hal yang sama juga terjadi Kota Baubau, di mana penduduk yang bermukim di area jangkauan gerombolan diangkut ke kota. Sebagai gambaran, berikut ini disajikan arsip sebagai bukti kontribusi kekacauan politik pada perkembangan kota seperti berikut ini.

A1. "Sesuai pembicaraan kami (Muh. Mansjur, Kepala Pemerintah negeri Laiwui) dengan sipil, militer dan polisi yang dihadiri oleh Andi Pengeran (Residen Koordinator), Comandan Sektor, Singa, Wakil teritorium VII Kapten Sutowo dan saudara sediri pada 20 November 1955 di rumah kepala pemerintah negeri Kendari, dengan agenda mengenai pengungsian:

1. Kesimpulan: Kapten Makatang dg. Sibali mengusulkan bahwa dengan operasinya baru2 ini telah merampas 82 orang yang ditampung di kamp BPT Kendari di Tipulu. Jauh pengungsian ini adalah $120 \mathrm{~km}$ dengan menggunakan otto partikelir atas kebijaksanaan komandan Sektor Singa. Para pengungsi ini tidak mau kembali lagi dan mereka bersedia bermukim di sekitar teluk kendari. Beliau sebenarnya hendak mengungsikan 1500 orang tetapi apa daya, peralatan dan keperluan pengangkutan kurang atau tidak ada sama sekali. Beliau perlu dibantu jaminan2 dan para pengungsi itu sangat kurus dan lemah. Mereka berasal dari orang-orang tolaki, Moronene dan Bugis. Sekitar 2000 an lainnya masih di tangan gerombolan.

2. Berkaitan dengan itu, saya sangat memuji inisiatif kapten Makatang dg. Sibali dan Kapten Kahar serta Mayor Sastroatmodjo (dari Brawijaya), maka perlu perhatian sebagai berikut yakni mengadakan pengungsian besar2an seperti yang terjadi pada tahun $1952 / 1953$

a.Penduduk yang dirasa perlu diungsikan dari daerah gerombolan ialah sasaran I dan II -Daerah kecamatan Laiwui Selatan: kampong Roraya, Mareo, Lanowulu, Motulo, Bou-bou Pundowo Atori. Pengungsi sebesar 1500 jiwa

- Dari daerah Ambekairi pernah diusulkan tahun 1954 namun gagal diungsikan ke Wawotobi. Perkiraan pengungsi sejumlah 1800 jiwa. Perundingan melibatkan Abdul Kadir Junus dengan Daeng Pawangkang pada tanggal 23 Maret 55 dan 15 April 1955.

- Perladangan dan persawahan yang mereka kerjakan sebelumnya telah bersedia ditinggalkan oleh para pengungsi.

b. 82 jiwa yang mengungsi ke Kendari ditempatkan di Andonohu, dan rencana tempat pengungsian lainnya ke arah Sampara sekitar $4 \mathrm{~km}$ ).

untuk A2. Tetap sebagaimana Tobeu dan Sambaeni dekat dengan pengungsian Rahabangga bisa menapung 1800 jiwa.

Pengungsian dilakukan dengan bantuan oto-oto. Pengungsian yang melalui air menggunakan bamboo yang tersedia di sekitar lokasi.

Sebelum dilakukan pengungsian telah dilakukan perbaikan jalan dan jembatan khususnya Roraya, Tinanggea, Palangga, Kendari, Jembatan Abekairi.

Di Kendari diadakan bangsal-bangsal penampungan dan juga di Tobeu.

Dibentuk panitia pengungsian di kecamatan Kendari

Biaya yang diperlukan dari pemeritah 50.000 melalui kepala djawaan social.

Yang dibutuhkan, pakaian, beras, sarung untuk 2000 jiwa. Selain iu diperlukan bibit padi untuk perladangan dan bibit ketela dan patjul-patjul.” 
Apabila mencermati isi dokumen arsip koleksi Provinsi Sulawesi Selatan di atas, maka bisa dipetakan seperti berikut ini, yakni kondisi pengungsi, wilayah penempatan, jumlah, dan kebutuhan serta kaitannya dengan perkembagan kota dari sisi infrastruktur, demografi, dan perluasan morfologi/pemukiman di kota. Kondisi korban dari kekacauan politik itu sebagaimana dalam arsip ada 82 orang yang ditampung di kamp BPT Kendari di Tipulu dan jumlah pengungsi yang mencapai 1800an orang. Lebih dari 2.000 orang masih ditawan pemberontak sehingga perlu penanganan berupa pembebasan sandra. Para pengungsi itu berasal dari orang-orang Tolaki, Moronene, dan Bugis. Kondisi pengungsi makin lemah karena peralatan yang terbatas dan dan bantuan yang tidak memadai.

Area penampungan pengungsi adalah wilayah Kecamatan Laiwui Selatan, yakni Kampong Roraya, Mareo, Lanowulu, Motulo, Bou-bou Pundowo Atori. Pengungsi di wilayah tersebut mencapai 1.500 jiwa. Para pengungsi itu telah meninggalkan persawahan dan kebun mereka untuk mencari keamanan di kota. Area lain yang juga menampung pengungsi adalah Tobeu dan Sambaeni yang lokasinya berdekatan dengan kamp pengungsian Rahabangga, yang mampu menampung 1.800 jiwa. Mobilisasi dan pengangkutan para pengungsi itu dilakukan dengan bantuan oto-oto (mobil) dan melalui air dengan menggunakan bambu (rakit) yang tersedia di sekitar lokasi, khususnya penyeberangan melalui sungai yang belum mempunyai jembatan.

Pada saat yang sama, untuk memperlancar arus mobilitas penduduk dan mobilisasi tentara dalam mengangkut pengungsi dan operasi pembebasan sandera, telah dilakukan perbaikan jalan dan jembatan (Roraya, Tinanggea, Palangga, Kendari, dan Jembatan Abekairi). Di Kota Kendari dan Tobeu didirikan bangsal-bangsal untuk penampungan pengungsi. Panitia untuk mengkoordinir pengungsi juga dibentuk di kecamatan Kendari, dan biaya yang dibutuhkan mencapai Rp 50.000 berasal ari anggaran pemerintah. Bantuan yang diharapkan adalah penyediaan pakaian, beras, sarung untuk 2.000 jiwa. Selain iu diperlukan bibit padi untuk perladangan dan bibit ketela dan patjulpatjul.

Realitas di atas telah membuktikan bagaimana kekacauan politik ikut berkontribusi pada perkembangan infrastruktur kota. Infrastruktur kota, fasilitas kota, dan penyediaan pemukiman baru di kota yang melibatkan pemangku kepentingan terutama militer (Rabani 2016). Tampak jelas bahwa sebagian dari perkembangan kota ternyata dipengaruhi oleh kekacauan politik, khususnya dalam kasus dua kota di Sulawesi Tenggara, Baubau dan Kendari. Pengungsi yang datang ke kota telah memperluas ruang dan menambah penduduk kota. Mereka juga telah menambah persediaan bahan pangan, sarana transportasi, dan sebagainya. Secara teoretis, bertambahnya perumahan dan penduduk kota berbanding lurus dengan meningkatnya kebutuhan si sektor ekonomi lainnya seperti sektor informal dan munculnya industri rumah tangga di perkotaan.

\section{SIMPULAN}

Episode sejarah dua kota, Baubau dan Kendari, yang menjadi fokus artikel ini membuktikan bahwa kekacauan politik dan ekonomi berimplikasi pada perkembangan kota. Perkembangan itu dapat diidentifikasi pada bertambahnya penduduk kota, pembangunan infrastruktur kota, penambahan fasilitas kota, dan perluasan area pemukiman di dalam kota. Kehadiran ribuan pengungsi dari daerah pinggiran kota telah memaksa pemerintah kota dan jajarannya untuk menyiapkan perumahan dan sumber pangan pada mereka, sehingga lahan baru pertanian di sekitar kota juga dibuka, karena adanya keterbatasan sumber pangan dan bantuan pangan untuk pengungsi.

Kehadiran militer dalam rangka melakukan pembebasan pada penduduk yang ditawan gerombolan mempercepat infrastruktur fisik wilayah seperti pembangunan asrama, perumahan, jembatan, jalan, dan barak-barak pengungsian. Kondisi itu tidak saja ikut menambah jumlah penduduk kota, tetapi 52 
juga memberi warna lain dari dua kota yang diteliti, yakni terjaminnya keamanan dan terciptanya kenyamanan pada sebagian penduduk kota.

Gangguan politik dan ekonomi pada periode 1950-an-1960-an di dua kota, Baubau dan Kendari, di satu sisi meninggalkan bekas "penderitaan," tetapi di sisi yang lain, kota menjadi ramai, toleransi dan kebersamaan ikut terbangun, serta munculnya kesadaran bahwa suasana aman menjadi syarat utama mewujudkan pembangunan yang lebih cepat. Terlepas dari kondisi pengungsi yang menyedihkan, kekacauan politik ternyata memiliki dampak pada perkembangan kota, khususnya untuk kontek tahun 1950-an sampai 1960-an. Namun demikian, tulisan ini menyarankan bahwa mengembangkan danmembangun kota tidak harus didahului dengan kekacauan politik atau ekonomi. Biarlah sejarah dua kota itu menjadi pelanjaran bahwa membangun dan mengembangkan kota pada suasana ekonomi dan politik yang tidak stabil, tidak semaksimal membangun dan mengembangkan kota dalam suasana damai.

\section{UCAPAN TERIMA KASIH}

Saya menyampaikan terima kasih kepada Prof. Dr. Bambang Purwanto, M.A. yang telah memberi saran-saran yang diperlukan untuk ide dan diskusi substantif yang ada dalam artikel ini. Ucapan terima kasih juga disampaikan kepada Dr. Sri Margana, M.Phil. yang juga telah memberi saran perbaikan dalam artikel ini. Beliau berdua, Prof. Bambang Purwanto (Promotor) dan Dr. Sri Margana, M. Phil. (Co-Promotor) dalam menulis disertasi dengan tema "Sejarah Ekonomi kota-kota Pelabuhan di Sisi Barat Laut Banda 1890-an-1960-an.” Data yang ada dalam artikel ini diambilkan dari sebagian data untuk penelitian disertasi.

\section{DAFTAR PUSTAKA}

Andaya, Leonard Y. 2004. Warisan Arung Palakka, Sejarah Sulawesi Selatan Abad Ke-17. Makassar: Ininnawa.

Arsip Daerah Kendari, Catatan hasil sidang DPRDS tahun 1954.

Bothe, A. CHR. D. 1928. "De Asfaltgesteenten van Het Eiland Boeton, Hun Voorkomen En Economische Beteekenis." De Ingenieur; M. Mijnbouw 19 (4): 27-45. https://resolver.kb.nl/resolve?urn=dts:2945099:mpeg21:pdf.

Broersma, R. 1931. “De Beteekenis van Selebes' Oostkust Voor Den Handel.” Tijdschrift van Het Koninklijk Nederlandsch Aardrijkskundig Genootschap DEEL XLVIII (TWEEDE SERIE): 10391050.

DPRD, Sulawesi Tenggara. 1977. Documenta DPRD Sulawesi Tenggara. Kendari: DPRD.

Duke, Said. 1997. "Pembentukan Propinsi Sulawesi Tenggara 1950-1978: Studi Konflik Dan Integrasi.” Jakarta: Universitas Indonesia.

Feith, Herbert. 1999. Pemilihan Umum 1955 di Indonesia. Jakarta: KPG.

Findlay, Ronald, dan Kevin H O'Rourke. 2001. "Commodity Market Integration, 1500-2000." Working Paper 8579:1.

Gottschalk, Louis. 1985. Mengerti Sejarah, diterjemahkan oleh Nugroho Notosusanto. Jakarta: Universitas Indonesia. 
Hadara, Ali. 1987. "Sistem Pelayaran dan Perdagangan Masyarakat Kepulauan Wakatobi: Tinjauan Kependidikan Sejarah.” Kendari: Univesitas Haluoleo.

Haeruddin. 2013. Akhir dari Persekutuan, Aneksasi Buton Dalam Pax Neerlandica 1900-1918. Yogyakarta: Ombak.

Harvey, Barbara S. 1987a. Kahar Muzakar, Dari Tradisi Ke DI/TII. Jakarta: Grafiti Press.

- 1987b. Kahar Muzakar, Dari Tradisi Ke DI/TII. Jakarta: Grafiti Press.

Instruksi Menteri Dalam negeri No. 1/PD tanggal 29 September 1959 Lamp. B

Kawat Rahasia, Kepala Pemerintahan Negeri Laiwui Kendari, No. Pem 3/x/1/420, tanggal 23 November 1955

Keputusan Mendagri No. Des.2/5/49, tanggal 17 April 1949

Klift, H. van der. 1933. "De Ontwikkeling van Het Zendingswerk Op Z. O. Celebes.” Tijdschrift Voor Zendingswetenschap "Mededeelingen" 77ste Jaargang:161-77.

Knaap, Gerrit, and Heather Sutherland. 2004. Mansoon Traders: Ships, Skippers and Commodities in Eighteenth-Century Makassar. Leiden: KITLV Press.

Kuntowijoyo. 1995. Pengantar Ilmu Sejarah. Yogyakarta: Bentang.

Melamba, Basrin, Abdul Azis Salahuddin, dan La Janu. 2011. Kota Lama Kota Baru Kendari, Kajian Sejarah Sosial, Politik, dan Ekonomi. Yogyakarta-Kendari: Teras bekerja sama dengan LAT dan Lembaga Pengembangan Pengkajian Sejarah dan Kebudayaan Sultra.

Noor, M. Mulki Mulyadi. 2019. "Kendari Port Development: The Meeting Point of Shipping and Trade Route in East Coast of Sulawesi, 1831-1945." Journal of Maritime Studies and National Integration 2 (2):75-85.

Ordonantie Indonesia no. 143 tahun 1946.

Parimartha, I Gde. 2002. Perdagangan dan Politik di Nusa Tenggara 1815-1915. Jakarta: Djambatan.

Peraturan Pemerintah No. 34 tahun 1952, pasal 3.

Poelinggomang, E.L. 2004. Perubahan Politik dan Hubungan Kekuasaan Makassar 1906-1942. Yogyakarta: Ombak.

Rabani, La Ode. 2005a. "Dari Kota Buton ke Kota Bau-Bau: Studi tentang Perubahan Nama Kota 1930-1960.” Jakarta: kerja sama LIPI-NIOD.

- 2005b. "Morfologi dan Infrastruktur Kota Buton 1911-1964." Dalam Kota Lama Kota Baru, Sejarah Kota-Kota di Indonesia, disunting oleh Freek Colombijn. Yogyakarta: Kerja sama Ombak dan NIOD. 
- 2005c. "Morfologi dan Infrastruktur Kota Buton 1911-1964." Dalam Kota Lama Kota Baru, Sejarah Kota-Kota di Indonesia, disunting oleh Freek Colombijn. Yogyakarta: Kerja sama NIOD, Jurusan Sejarah Unair, dan Ombak.

- 2009. "Industri Pertambangan Nikel dan Dampaknya pada Masyarakat Soroaka Sulawesi Selatan.” Jantra IV (8):630-640.

- 2010a. Kota-Kota Pantai di Sulawesi Tenggara. Yogyakarta: Ombak.

—. 2010b. "Social Movements in Southeast Sulawesi, 1906-1942." Jurnal Humaniora 22 (1):1421. doi: $10.22146 /$ jh.v22i1.981.

- 2016. "Menafsir Ulang Sejarah Perkembangan Kota Kendari: Implikasi dari Kekacauan Sosial Sebelum dan Sesudah Kemerdekaan.” Dalam Jaringan Kebangsaan Antar-Nusa. Padang: Masyarakat Sejarawan Indonesia bekerja sama dengan Universitas Andalas.

- 2019. "Commercial Activities and Development of the Towns in the West Side of Banda Sea Indonesia, Early Twentieth Century." Dalam Urban Studies: Border and Mobility. London dan New York: Routledge.

Sangaji, Arianto. 2002. Buruk Inco, Rakyat Digusur: Ekonomi Politik Pertambangan Indonesia. Jakarta: Pustaka Sinar Harapan.

Schoorl, J. W. 1991. "Het 'Eeuwige' Verbond Tussen Buton En de VOC, 1613-1667." Dalam Excursies in Celebes: En Bundel Bijdragen Bij Het Afscheid van J.Noorduyn Als Directeuursecretaris van Het Koninklijk Instituut Voor Taal- Land- En Volkenkunde, disunting oleh Harry A. Poeze. Leiden: KITLV Press.

SK Mendagri no.2/2/42 tanggal, 19 Februari 1953.

Stapel, F. W. 1922. "Het Bongais Verdrag." Leiden: Rijksuniversiteit.

Staten-Generaal, Handelingen der. 1923. "Koloniaal Verslag van 1923 Nederlandsch Oost-Indie." Gedrukt ter Algemeene Landsdrukkerij.

—. 1924. "Koloniaal Verslag van 1923 Nederlandsch Oost-Indie.” Gedrukt ter Algemeene Landsdrukkerij.

Surat Ketua Dewan Pleno Persiapan Darah Tingkat II Mekongga No. 001/D.P./ 59, Agenda No. 74/810/59, tanggal 12 Mei 1959. Koleksi Arsip Daerah Kendari.

Sutherland, Heather. 2004. "Kontinuitas dan Perubahan dalam Sejarah Makassar: Perdagangan dan Kota di Abad Ke-19.” Dalam Kontinuitas dan Perubahan Sejarah Sulawesi Selatan, disunting oleh Muslimin A. R. Effendy. Yogyakarta: Ombak.

Syahadat, Ray March, Nurhayati HS Arifin, dan Hadi Susilo. 2016. "Lanskap Kolonial Kota Baubau Sebuah Pusaka Peninggalan Masa Kolonial di Sulawesi Tenggara.” Paramita: Historical Studies Journal 25 (2):185-195. 
Talha, M. Arsyad. 1982. Kabupaten Sulawesi Tenggara ke Status Propinsi. Kendari: Biro Hukum Pemda Tk. I Sultra.

Velthoen, Esther J. 2005. "Sailing in Dangerous Waters: Piracy and Raiding in Historical Context." IIAS News Letter (March).

- 2010. "Pirates in Periphery: Eastern Sulawesi 1905." Dalam Pirates, Ports, and Coasts in Asia, Historical and Contemporary Perspectives, disunting John Kleinen and Manon Osseweijer. Singapore: ISEAS.

Vogel, W. Th. de. 1916. "Report about of the Investigations Carried out with Regard to the Sanitary Condition of the Port of Sibolga, Residency Tapanoeli, from 24th April until 6th May 1913." Mededeelingen van Den Burgerlijken Geneeskundigen Dienst in Nederlandsch-Indië, Anno 1915, Deel IV, Batavia-Landsdrukkerij:62-98.

Vosmaer, J. N. 1839. "Korte Beschrijving van Het Zuid-Oostelijk-Schiereiland van Celebes." Verhandelingen van Het Bataviaasch Genootschap van Kunsten En Wetenschappen 17.

Zahari, A. M. 1977. Sejarah dan Adat Fiy Darul Butuni (Buton), Vol. I. Jakarta: Depdikbud. 